Mathematical Modelling and Analysis

Volume 5, 2000, PAGeS 26-31

(C) 2000 Technika

\title{
A MATHEMATICAL MODEL OF PAPER DRYING
}

\section{J. CEP̄̄TIS}

Institute of Mathematics

Latvian Academy of Sciences and University of Latvia

Akadēmijas laukums 1, LV-1524 Rīga, Latvia

E-mail: cepitis@lanet.lv

Received September 30, 1999

\begin{abstract}
The mathematical model of wood drying based on a detailed transport phenomena considering both heat and moisture transfer have been offered in the article [5]. We apply this model to quickly moving paper sheet. The range of the moisture content correspond to the period of drying and only vapor movement in the web is possible. By averaging we have obtained the desired model as a system of two nonlinear first order ordinary differential equations.
\end{abstract}

\section{INTRODUCTION}

Some time ago we began treatment of the mathematical models for wood drying and saturating processes. Our collective elaboration was presented in the 10th conference of ECMI in Goeteborg, Sweden, June 23-28, 1998 and after that the report [1] was published.

In the construction in of the mathematical model we neglected temperature changes during the drying and saturating processes. In spite of this fact, results obtained for a thin fiber plate which was dried under the constant temperature had a good agreement with practice.

Of course, the temperature variation is a very significant factor in wood or paper processing. This notice is devoted to some aspects of the consequent trend of investigations - we take into account temperature gradients for mathematical modelling of paper drying.

The wet web from the press section is passed over a series of rotating steamheated cylinders where water is evaporated and carried away by ventilation air. Relevant details of this process are described following [6]. 


\section{ZONES OF DRYING}

Let the moisture content $M$ of web is defined by ratio

$$
M=\frac{m_{w}}{m_{f}},
$$

where $m_{w}$ is the mass of water (including water vapor), $m_{f}$ is the mass of fibers in a given volume of web, and consider the variable $M$ as the function of time $t$.

At beginning the drying section (warm-up zone) serve principally to raise the temperature of the paper sheet. Evaporation then quickly reaches a peak rate which is maintained as long as water is present on the fiber surfaces or within the large capillaries (constant rate zone). At the point where the remaining free moisture is concentrated in the smaller capillaries, the rate begins to decrease (falling rate zone). Finally, at about 0.09 of moisture content, the residual rates within the sheet is more tightly held by physicochemical forces, and the evaporation rate is further reduced (bound water zone).

Graphics of the function $M(t)$ during the drying process is convex in the warm-up zone, linear in the constant rate zone, concave in the falling rate zone and very slowly diminishing in the bound water zone.

For all factors being equal, the more evaporation takes place in the constant rate zone, the higher will be the average evaporation rate. By the same analysis, the average rate will be lower if a significant amount of time is spent in the bound water zone. Moreover, paper machines are forced to "over-dry" in order to compensate for poor drying uniformity.

So, the constant rate zone is most significant if we want to apply of results obtained by the mathematical modelling.

On the other hand, the whole process of drying can be divided into three periods according to the moisture content level. The moisture content in paper bulk $M$ is greater than the minimum value $M_{2}$ for liquid continuity in the first period. During this period liquid movement and vapor flow occur. Further, the moisture content $M$ is less than the value $M_{2}$ but greater than the value $M_{1}$ of fiber saturation, in which period only vapor movement is possible. Finally, the moisture content $M$ falls below the value $M_{1}$, when vapor movement and bound water diffusion control the drying.

\section{AREA OF THE MATHEMATICAL MODELLING}

Let $j$ denotes the total moisture flux in the web. We have $j=j_{b}+j_{v}+j_{f}$, where $j_{b}$ is the bound water flux, $j_{v}$ is the water vapor flux, $j_{f}$ is the liquid water flux. Particularly based on the above classification we can write

$$
\begin{gathered}
j=j_{b}+j_{v}, \quad M<M_{1}, \\
j=j_{v}, \quad M_{1} \leq M<M_{2},
\end{gathered}
$$




$$
j=j_{v}+j_{b}, \quad M_{2} \leq M .
$$

Following [5] the moisture fluxes $j_{b}, j_{v}, j_{f}$ satisfy Darcy's law and are given by the expressions:

$$
\begin{gathered}
j_{b}=-D_{b}(1-\varepsilon) \frac{\partial \mu_{b}}{\partial x} \\
j_{v}=-\frac{K_{v} \rho_{v}}{\mu_{v}} \frac{\partial p_{v}}{\partial x} \\
j_{f}=-\frac{K_{1} \rho_{1}}{\mu_{1}} \frac{\partial p_{1}}{\partial x}
\end{gathered}
$$

where $D_{b}$ denotes the bound water diffusion coefficient, $\varepsilon$ is the voidage of web, $\mu_{b}$ is the chemical potential of bound water, $K_{v},\left(K_{1}\right)$ is the pulp permeability to water vapor (liquid) flow, $\mu_{v},\left(\mu_{1}\right)$ is the water vapor (water) viscosity, $\rho_{v},\left(\rho_{1}\right)$ is the density of water vapor (water), $p_{v},\left(p_{1}\right)$ is the partial vapor (liquid) pressure.

Note, that the physical parameters involved in these expressions are of two kinds. In the first place there are constants depending only on the water vapor properties which are carefully investigated and described in literature. On the other hand, some parameters (particularly, permeability to flow) are specific for the concrete material of web which is dried.

So, we can see for oneself that the minimal number of various physical parameters connected with real processing for mathematical describing of moisture fluxes will be necessary in the case $M \in\left[M_{1}, M_{2}\right)$.

The temperature depending value $M_{1}$ is defined by the following expression in the paper [2]

$$
M_{1}=\frac{34.1-0.133 T}{100},
$$

where $T$ is the temperature. Therefore the value $M_{1}$ is situated in the falling rate zone near to its left endpoint.

Now it is possible to conclude that the domain $\left[M_{1}, M_{2}\right)$ corresponds to the beginning of falling rate zone and to the end of constant rate zone in which the graphics of the function $M(t)$ is linear. As it was mentioned above the constant rate zone also is more significant in the sense of real paper processing. Therefore the most important task is fitting of the mathematical model for $M \in\left[M_{1}, M_{2}\right)$. Further, taking into account the behavior of the graphics of the function $M(t)$ in the neighbouring zones of drying, it is possible to continue the obtained curve.

\section{THE MATHEMATICAL MODEL}

Heat transfer and moisture mass balance equations have been derived within web (see, [5]). Since we are considering area $M \in\left[M_{1}, M_{2}\right)$ these equations 
are respectively:

$$
\begin{aligned}
c_{p} \rho_{w} \frac{\partial T}{\partial t} & =\frac{\partial}{\partial x}\left(\lambda \frac{\partial T}{\partial x}\right)-H_{w v} \frac{\partial j_{v}}{\partial x}, \\
& -\rho_{w} \frac{\partial M}{\partial t}=\frac{\partial j_{v}}{\partial x}
\end{aligned}
$$

where $c_{p}$ denotes the specific heat of web, $\rho_{w}$ is the basic density, $\lambda$ is the thermal conductivity of web, $H_{w v}$ is the heat of vaporization of water.

As far as values of the moisture content $M>M_{1}$ are considered, the equality $p_{v}=p_{s}$ is true, where $p_{s}$ denotes the vapor pressure at the saturation condition. Therefore as

$$
\frac{\partial p_{s}}{\partial M}=0
$$

we can substitute

$$
\frac{\partial p_{v}}{\partial x}=\frac{\partial p_{v}}{\partial T} \frac{\partial T}{\partial x}
$$

in the expression (3.1) Moreover, following [4] we can use expressions

$$
\begin{gathered}
\frac{\partial p_{s}}{\partial T}=307 \times 10^{f(T)} f^{\prime}(T), \\
f(T)=16.3737-\frac{2818.6}{T}-1.6908 \lg (T)-5.7546 \times 10^{-3} T+4.00073 \times 10^{-6} T^{2} .
\end{gathered}
$$

For the density of water vapor $\rho_{v}$ according to the universal gas law it is possible to write

$$
\rho_{v}=\frac{p_{v} \tilde{M}_{v}}{R T}
$$

where $\tilde{M}_{v}$ is the molar mass of vapor, $R$ is the universal gas constant.

The thermal conductivity of web can be evaluated by expressions [7]

$$
\begin{gathered}
\lambda=\frac{4.19}{36}\left[0.001867 \rho_{w}+0.00348 M \rho_{w}+0.205 \varepsilon\right], \\
\varepsilon=1-\frac{\rho_{w}}{1000}\left(\frac{2}{3}+M_{1}-M\right) .
\end{gathered}
$$

Furthermore, the specific heat of web can be evaluated by the expression [7]:

$$
c_{p}=(0.266+0.00116 T+M) \times 4190 .
$$

Taking into account (3.1), we can rewrite the heat transfer and moisture mass balance equations in the subsequent form:

$$
\frac{\partial T}{\partial t}=\frac{\partial}{\partial x}\left[E_{h}(M, T) \frac{\partial T}{\partial x}\right]
$$




$$
\frac{\partial M}{\partial t}=\frac{\partial}{\partial x}\left[E_{m}(M, T) \frac{\partial T}{\partial x}\right]
$$

where

$$
\begin{gathered}
E_{m}(M, T)=\frac{1}{\rho_{w}} E, \quad E_{h}(M, T)=\frac{1}{c_{p} \rho_{w}}\left(\lambda+H_{w v} E\right), \\
E=\frac{307 \times 10^{f(T)} f^{\prime}(T) \rho_{v} K_{v}}{\mu_{v}} .
\end{gathered}
$$

Paper drying can be visualized as a repetitive two-phase process. In phase 1 , the sheet picks up sensible heat while being in contact with the steam cylinder. In phase 2 , the sheet flashes off steam in the open draw between the top and bottom cylinders, thus causing the sheet to spontaneously cool and become ready to pick up sensible heat again.

Let $U_{0}$ be the velocity of paper sheet pulling, $d_{i}$ is the length of drying phase with number $i=1,2, \delta$-the thickness of paper sheet, $\tau_{i}=\frac{d_{i}}{U_{0}}$, choose $x$ - axis perpendicularly to paper sheet and consider in time movement of fixed cross-section of paper sheet during two sequential drying phases.

Taking into account the convective heat transfer with external surroundings, we obtain the following boundary conditions:

$$
\begin{gathered}
\frac{\partial T}{\partial x}(t, 0)=\kappa\left(T(t, 0)-T_{f}\right), \quad \frac{\partial T}{\partial x}(t, \delta)=\alpha\left(T_{a}-T(t, \delta)\right), \quad t \in\left[0, \tau_{1}\right), \\
\frac{\partial T}{\partial x}(t, 0)=\alpha\left(T(t, 0)-T_{a}\right), \quad \frac{\partial T}{\partial x}(t, \delta)=\alpha\left(T_{a}-T(t, \delta)\right), \quad t \in\left[\tau_{1}, \tau_{1}+\tau_{2}\right),
\end{gathered}
$$

where $T_{f}$ is the temperature of steam cylinder, $T_{a}$ is the temperature of air. $T_{f}, T_{a}$ are time dependent variables, the coefficients $\alpha, \kappa$ depend also on the temperature $T$ of paper sheet. For evaluating these coefficients we can use expressions offered in the article [3]. For example, in the second phase of drying we take

$$
\alpha(t, T)=0.044\left(\frac{d_{2} U_{0}}{\nu_{a}}\right)^{0.77} \frac{T}{T_{a}(t)} \frac{k_{a}}{d_{2}},
$$

where $\nu_{a}$ is the kinematic viscosity, $k_{a}$ is the thermal conductivity of air.

Let us introduce the averaged variables

$$
m(t)=\frac{1}{\delta} \int_{0}^{\delta} M(t, x) d x, \quad \Theta(t)=\frac{1}{\delta} \int_{0}^{\delta} T(t, x) d x .
$$

Using procedure of averaging (similarly as it was done in [3]) we obtain systems of two first order nonlinear ordinary differential equations:

$$
\frac{d \Theta}{d t}=\frac{E_{h}(m, \Theta)}{\delta}\left[\alpha T_{a}+\kappa T_{f}-(\alpha+\kappa) \Theta\right],
$$




$$
\frac{d m}{d t}=-\frac{E_{m}(m, \Theta)}{\delta}\left[\alpha T_{a}+\kappa T_{f}-(\alpha+\kappa) \Theta\right]
$$

(for the first phase of drying), and

$$
\begin{aligned}
& \frac{d \Theta}{d t}=2 \alpha \frac{E_{h}(m, \Theta)}{\delta}\left(T_{a}-\Theta\right), \\
& \frac{d m}{d t}=2 \alpha \frac{E_{m}(m, \Theta)}{\delta}\left(T_{a}-\Theta\right)
\end{aligned}
$$

(for the second phase of drying).

The obtained mathematical model of paper drying consists of the sequence of initial value problems for these systems and this model is applicable for the range of values of moisture content $M \in\left[M_{1}, M_{2}\right)$.

\section{REFERENCES}

[1] A.Aboltins, A.Buikis, J.Cepitis, H.Kalis and A.Reinfelds. Diffusion and chemical attachment of substances with simple molecular structure in wood. In: Proc. of the 10th Conference ECMI, Goeteberg, Sweden, 1998, Progress in Industrial Mathematics at ECMI 98, L.Arkeryd, J.Bergh, Ph.Brenner and R.Petterson (Eds.), B.G.Teubner, Stuttgart/Leipzig, 1999, 188-195.

[2] G.Bramhall. Mathematical model for lumber drying. I.Principles involved. Wood Science, 12 (1), 1979, 14-21.

[3] A.Buikis, A.D.Fitt. A mathematical model for the heat treatment of glass fabric sheets. IMA Journal of Mathematics Applied in Business and Industry, 9, 1998, 1-32.

[4] F.Kayihan. Simultaneous heat and mass transfer with local three-phase equilibria in wood drying. In: Proc. 3rd International Drying Symposium, 1, 1982, 123-134.

[5] S.Pang. Relationship between a diffusion model and a transport model for softwood drying. Wood and Fiber Science, 29 (1), 1997, 58-67.

[6] G.A.Smook. Handbook for Pulp and Paper Technologists. Angus Wilde Publications, Vancouver, 1992.

[7] A.J.Stamm. Wood and Cellulose Science. Ronald Press, New York, 1964.

\section{POPIERIAUS DŽIOVINIMO MATEMATINIS MODELIS}

\section{J. CEPITIS}

Straipsnyje remiamasi [5] darbu, kuriame buvo pasiūlytas detalus šilumos ir drègmès perdavimo medyje matematinis modelis. Autorius pritaiko šiuos rezultatus popieriaus gamybos technologinio ciklo modeliavimui. Nagrinèjamas greitai judančios popieriaus masès džiovinimo procesas. Aptarti matematiniai modeliai, aprašantys temperatūros ir drègmès pokyčius i̇vairiose džiovinimo stadijose. Gautoji diferencialinių lygčių sistema vidurkinimo metodu pertvarkoma i seką dviejų paprastųjų diferencialinių lygčių sistemų, kur kiekviena sistema atitinka vieną džiovinimo cilindrą. 